\title{
Factors associated with male partner involvement in the prevention of mother-to-child transmission of human immunodeficiency virus in the Gokwe North District, Zimbabwe: A qualitative study
}

\begin{tabular}{|c|c|}
\hline \multicolumn{2}{|c|}{$\begin{array}{l}\text { Author: } \\
\text { Vimbai Chibango }^{1}\end{array}$} \\
\hline \multicolumn{2}{|c|}{$\begin{array}{l}\text { Affiliation: } \\
{ }^{1} \text { Research Focus Area: Gender } \\
\text { Justice, Health, and Human } \\
\text { Development, Office of the } \\
\text { DVC Research, Innovation, } \\
\text { and Engagement, Durban } \\
\text { University of Technology, } \\
\text { Durban, South Africa }\end{array}$} \\
\hline \multicolumn{2}{|c|}{$\begin{array}{l}\text { Research Project Registration: } \\
\text { Project number: } \\
\text { HSS/0003/014D }\end{array}$} \\
\hline \multicolumn{2}{|c|}{$\begin{array}{l}\text { Corresponding authc } \\
\text { Vimbai Chibango, } \\
\text { vimbaic@dut.ac.za }\end{array}$} \\
\hline \multicolumn{2}{|c|}{$\begin{array}{l}\text { Dates: } \\
\text { Received: } 03 \text { Apr. } 2020 \\
\text { Accepted: } 13 \text { July } 2020 \\
\text { Published: } 24 \text { Nov. } 2020\end{array}$} \\
\hline \multicolumn{2}{|c|}{$\begin{array}{l}\text { How to cite this article: } \\
\text { Chibango, V., 2020, 'Factors } \\
\text { associated with male partner } \\
\text { involvement in the } \\
\text { prevention of mother-to- } \\
\text { child transmission of human } \\
\text { immunodeficiency virus in } \\
\text { the Gokwe North District, } \\
\text { Zimbabwe: A qualitative } \\
\text { study', HTS Teologiese } \\
\text { Studies/Theological Studies } \\
76(3) \text {, a6022. https://doi. } \\
\text { org/10.4102/hts.v76i3.6022 }\end{array}$} \\
\hline \multicolumn{2}{|c|}{$\begin{array}{l}\text { Copyright: } \\
\text { (c) 2020. The Authors. } \\
\text { Licensee: AOSIS. This wC } \\
\text { is licensed under the } \\
\text { Creative Commons } \\
\text { Attribution License. }\end{array}$} \\
\hline \multicolumn{2}{|l|}{ Read online: } \\
\hline 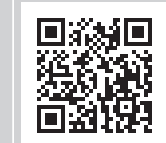 & $\begin{array}{l}\text { Scan this QR } \\
\text { code with your } \\
\text { smart phone or } \\
\text { mobile device } \\
\text { to read online. }\end{array}$ \\
\hline
\end{tabular}

Male partners' involvement in human immunodeficiency virus (HIV) intervention programmes is crucial in the prevention of mother-to-child transmission (PMTCT) of HIV. However, male partner involvement in PMTCT is low in most countries in Sub-Saharan Africa. Therefore, this study aimed at exploring the major factors associated with male partner involvement in PMTCT of HIV programmes in the Gokwe North District of Zimbabwe. The study utilised qualitative methods. Data was collected using a pretested interview guide. Purposive sampling methods were used to select participants of focus group discussions and key informant interviews. Interviews were conducted from May to September 2015. Thematic analysis was used for data analysis. The study revealed that local traditional leaders played a role in mobilising men in communities. Awareness campaigns enhanced communities' knowledge about PMTCT. Couple communication proved to be vital in promoting male involvement. However, stigmatisation against men utilising antenatal-care services, fear of HIV results and a lack of knowledge of the practices surrounding PMTCT of HIV programmes were hindrances to male partner involvement. Collaboration and engagement amongst stakeholders especially with traditional leadership can be essential in increasing male partner participation in PMTCT. Education has proved to be a catalyst in the de-stigmatisation of men in PMTCT programmes. Moreover, HIV counselling can illuminate an understanding on the implications of HIV test results. The significant contribution of this article is its demonstration of the role of African traditional leadership and belief systems in curbing HIV infections, particularly in terms of male partners' involvement in PMTCT initiatives.

Contribution: The significant contribution of this article is its demonstration of the role of African traditional leadership and belief systems in curbing HIV infections, particularly in terms of male partners' involvement in PMTCT initiatives.

Keywords: PMTCT; HIV; Male partner involvement; Male partner; African traditional leadership.

\section{Introduction}

Traditionally, prevention of mother-to-child transmission (PMTCT) programmes focussed on enabling women to utilise the intervention services, and less attention was paid to their male partners (Ngure et al. 2017). This made antenatal clinics seem as women's spaces and 'reproductive health' as women's health (Ramirez-Ferrero \& Lusti-Narasimhan 2012). The exclusion of men in these spaces eventually led to a failure of the women to fully utilise the PMTCT services because few men would test for human immunodeficiency virus (HIV) during their partner's pregnancy (Msuya et al. 2008). The involvement of the male partners in PMTCT programmes is crucial, mainly because in many African traditional families, men control the allocation of resources within their households and influence all decisions on family planning and reproductive health (Theuring et al. 2009).

Men's influence on decision-making and on women's utilisation of PMTCT services is often common in societies whose cultures are predominantly patriarchal. There is a wide variety of perspectives on what culture is (Beyers 2017). Figl (2003 cited in Beyers 2017:2) defines culture as the 'widest ethnographic sense to refer to knowledge, beliefs, art, ethics, customs, practices and skills which humans as members of a community have acquired' (Figl 2003 cited in Beyers 2017:2).

Note: Special Collection entitled Gender Justice, Health and Human Development, sub-edited by Cheryl Potgieter (DUT). 
The traditional African family in Zimbabwe is a patriarchal one in which men are considered as the heads of the households. Although this seems to be changing over time, this culture has been maintained since time immemorial. In matters concerning health, such as HIV prevention, generally men continue to have influence on how women utilise certain HIV prevention services, including PMTCT services. For example, a Zimbabwean Demographic Health Survey (ZDHS) of 2015 (ZDHS 2016) suggests that although the rate of access to contraception by women has risen to $67 \%$ since ZDHS 2010, generally husbands decide on the family planning method to be used, the number of children and the spacing between each child. It was also found that men wanted to learn more about family planning so that they could make informed decisions. Moreover, the use of femalecentred contraceptives may be highly influenced by the male counterparts as they may mediate the economic resources needed to access contraceptives or indirectly sanction or prohibit their use (Dudgeon \& Inhorn 2004).

The involvement of male partners (MPI) in voluntary counselling and testing (VCT) and other procedures within PMTCT programmes has proved beneficial in many ways (Aarnio et al. 2009; Manjate-Cuco et al. 2015; WHO 2012). A study in Tanzania describes the prevalence and predictors of male partner participation in HIV VCT at two primary healthcare clinics (Msuya et al. 2008). Their results showed that HIV-seropositive women whose partners attended the clinics were more likely to use nevirapine prophylaxis (NVP) and adhere to the infant feeding method selected than those whose partners did not attend the clinics.

Participation of male partners in VCT usually reduces the burden of the woman in having to disclose her HIV status on her own, as well as informing the partner of the correct measures to be taken to avoid HIV transmission to the child. Previous studies show that mothers who receive HIV-positive test results often find it difficult to disclose their status to their partners for fear of stigmatisation, divorce or domestic violence (Kalembo et al. 2012; Medley et al. 2004; Njunga \& Blystad 2010); yet, without disclosure to their partners, it becomes difficult for mothers to employ the necessary measures that prevent HIV transmission to their babies during pregnancy and after birth.

Evidence from previous studies portrays an association between MPI and spousal communication on HIV and sexual risk (Mabachi et al. 2020; Reece et al. 2010; Tonwe-Gold et al. 2009). Studies conducted in Kenya (Mabachi et al. 2020; Reece et al. 2010) assessed male spousal engagement in the PMTCT of HIV programmes and found that good couple communication was associated with high levels of HIV disclosure and support between male and female partners. Also, HIV-positive women whose partners did not receive HIV counselling and testing with them were less likely to disclose to their partners that they were taking antiretroviral therapy (ART) (Tonwe-Gold et al. 2009).
To date, various studies have been conducted in Zimbabwe on MPI in PMTCT. For example, the Organisation of Public Health Interventions and Development (OPHID) studied the health system factors that facilitated and constrained male partner participation in PMTCT services in the Mashonaland East Province of Zimbabwe (OPHID 2015). One of the few studies conducted in Zimbabwe evaluated an intervention programme that sought to measure male partner testing in PMTCT and community leaders' involvement in PMTCT interventions in Zimbabwe, Uganda and Swaziland (Woelk et al. 2016). Makoni et al. (2016) studied the factors enabling MPI, but their interest was only on the antenatal clinic environment. These studies provide important insights into the factors that are at play in MPI in PMTCT. However, they only focus on selected PMTCT services. Hence, this study aimed at developing a more rigorous understanding of the major factors that hinder or enable male partners to take part in PMTCT programmes in the Gokwe North District of Zimbabwe.

\section{Theoretical framework}

The study draws upon insights provided by the gender and development (GAD) theory. Gender and development theory is one of the emancipatory theories, and according to Parpart, Connelly and Barriteau (eds. 2000) it:

$[A]$ dopts a two-pronged approach to the study of women and development, investigating women's material conditions and class position, as well as the patriarchal structures and ideas that define and maintain women's subordination. The focus is on relationships between women and men, not on women alone. (p. 62)

Accordingly, GAD takes into account women's subordination to men in the context of historically socially constructed gender relations (Moser 1993). Its basic principles are to bring holistic equality between men and women; however, addressing women's issues without including men is assumed insufficient as their contribution will influence positive institutional change. Tolhurst et al. (2012), in their analysis of gender mainstreaming health programmes, argue that addressing hegemonic masculinities must benefit both men and women. Moreover, interventions aimed at engaging men and boys within health interventions have used the gender transformative approach, as it is seemingly more effective in changing men's behaviour and attitudes (WHO 2009). Similarly, this approach ensures that in the process of incorporating men into such interventions, women are empowered to prevent unanticipated negative outcomes of men's involvement in health programmes (WHO 2009). In accordance with the GAD approach, this study sought understanding of the different factors that impact on men's involvement in PMTCT programmes in their communities, specifically by identifying and unpacking the gender roles that exist in the local community. Gender inequalities are often a common phenomenon within patriarchal societies, in which, for instance, men are often bestowed with the authority to control female access to medical treatments. 


\section{Methods}

This was a qualitative study that utilised focus group discussions (FGDs) and key informant interviews (KIIs) as the sources of primary data. The FGDs generated a common understanding and perceptions regarding the inclusion of males in PMTCT initiatives in the local context, and interaction amongst the participants of the focus group also reflected the (sub)cultural values and shared knowledge on the subject, according to Powell \& Single (1996). The KIIs were invaluable sources of information that provided first-hand knowledge about the community, as well as the PMTCT programmes that were being implemented in the district.

The study was conducted in Gokwe North, a rural district in the Midlands Province, northwest of Zimbabwe. The local administration in the district is under traditional chiefs, whose installation is considered as divine and believed to be approved by the metaphysical world (Ngara 2019). The chiefs assign village headmen, who live in the communities and assist the chief in ensuring that the cultural values and customs of the communities are observed.

The district is characterised by poor infrastructure, and its inhabitants have limited access to health facilities. There are about 18 health facilities, of which only two are hospitals, and the rest are clinics. The community relies largely on an agrarian economy, and it is renowned for being one of the leading producers of cotton in the country. Mvumi and Marimo (2011) note that basic HIV or -acquired immune deficiency syndrome (AIDS) knowledge is a challenge, and there are a few organisations implementing AIDS services in the area.

The participants were selected by using a purposive sampling method, which was aided by chain referral techniques. The participants of the KIIs were selected because they were stakeholders involved in PMTCT initiatives in the district. These included the heads of health-related organisations and community leaders. The participants of the FGDs were homogenous groups such as churches, healthcare centres and community project members. Each individual participant, however, was to be more than 18 years of age and have resided in the district for a minimum period of 1 year. It was assumed that after a year, a person would have become familiar with the local practices and events that occurred in the communities.

Interviews and participant observation were utilised for data collection. The FGDs and KIIs were conducted by using separate interview guides. A trained moderator facilitated the collection of data in the FGDs, whereas the KIIs were solely conducted by the principal investigator. Each interview lasted for approximately 1 h $30 \mathrm{~min}$ on average. All interviews were audio recorded, whilst field notes were documented on any important observations.
Thematic analysis was used for data analysis. This involved a thorough reading of the notes and verbatim transcriptions, so as to become familiar with the interviews. The themes or statements relevant to the study emerging from the data were identified and coded in each text, by using the NVIVO software. This was followed by organising the responses or statements into categories or subthemes, by way of grouping statements that had the same meaning or idea. This incorporated direct short and extensive quotes extracted from the interviews to ensure that the contextual meanings of vital issues were not lost.

\section{Results \\ Participants}

A total of seven KIIs and eight FGDs (two FGDs with men only, two FGDs with women only and four FGDs with a combination with both men and women) were conducted. Of the KII participants, four had managerial positions within the Ministry of Health in the district; two were from non-governmental organisations that provided healthcare services such as sexual and reproductive health, HIV and AIDS services, paediatric services and maternal health services; and one key informant was a traditional birth attendant.

Generally, participants in the study concurred on the importance of MPI as one of the efforts that could help prevent mother-to-child transmission of HIV. They described the major factors that they suggested promoted male partners' involvement. These included traditional leaders' support, couple communication and initiatives from the health institutions. Factors that were identified as hindrances included stigmatisation, lack of basic knowledge on HIV testing and fear of positive HIV test results.

\section{Traditional leaders' support of prevention of mother-to-child transmission interventions}

The findings of this study revealed that traditional leaders in the district played an important role in encouraging communities to take part in educational programmes conducted by healthcare workers, as well as in motivating the male partners to participate in the PMTCT programmes. About five of the eight key informants interviewed explained how beneficial it was to engage chiefs and headmen who motivated men to attend antenatal programmes that facilitated the PMTCT of HIV, and one key informant stated:

'As a district we started by having meetings with the chiefs, explaining to them the importance of male partners taking part in the interventions for prevention of mother-to-child transmission of HIV ... If a woman gets pregnant, the village head advises the man to go with his female partner to the clinic; we used to call it "Operation Perekedza Mukadzi Wako" [Operation Accompany Your Female Partner]. But unfortunately, as a district fewer men come because most men are busy at workplaces ... However, as a district we are leading in this operation because chiefs and headmen are also involved.' (Sam, male, 49 years) 
The quotes above demonstrate that MPI in the district has had positive results because of the support provided by community leaders such as the chiefs and village headmen. Leadership in the rural areas of Zimbabwe is composed of chiefs and village headmen, and these leaders yield enormous power in influencing activities conducted in the community. The strength of this approach was that it utilised local leadership, as they could easily relate to the community and had the power to influence change in the community; secondly, the approach enabled communities to have a sense of being part and parcel of the PMTCT programme, rather than mere passive recipients of these health interventions.

\section{Health systems initiatives}

The management of the health facilities in the district came up with local policies that emphasised that couples should come together to register their pregnancies. This method facilitated pregnant women having their husbands accompany them for testing during their antenatal visits. The clinics' requirement that women registering their pregnancies for the first time bring their husbands provided the health staff with the opportunity to conduct HIV counselling and testing with the couple:

'We have tried to find ways of bringing the men by advising women to bring the husband if he is around. In situations where we know the couple, we send the woman back and inform her husband that he is needed for the registration of the pregnancy to be successful. When the couple comes, then we can introduce and provide HIV testing and counselling as a process of registration of pregnancy.' (Ruva, female, 36 years)

In addition, women who were accompanied by their spouses to either antenatal care (ANC) or postnatal clinics were served earlier than those who came without their partners. This study's results showed that most men had responsibilities that made it impossible for them to wait in long queues. They had work and other commitments that demanded their presence, so providing services to couples first enabled women to motivate their partners to go to ANCs with them to some extent, as time would not be wasted. The following quotes demonstrated this view:

'[S]ome men cannot come with their wives to the clinic; not because they do not like to do so, but it is because they are working. This probably discourages them from coming if they are to stand in queues again. For this reason, we also give preference to women who come with their partners, so that these men can go back to their various work places.' (Ruva, female, 36 years)

Extended clinic operating hours during the weekdays were also made available to accommodate male partners who could not attend the clinic during regular working hours. In addition, weekend consultation hours were introduced to enable men who could not attend during the week to access the services on the weekend:

' $[A] \mathrm{s}$ an institution we have set extended operation hours at the clinic so that working men come with their wives after work. We are aware that one hour is not enough since some of them walk from work to the clinic; some will be coming from afar, hence we found it necessary to extend hours for them. This has increased the number of males coming to the hospital to visit their partners.' (Tonde, male, 47 years)

Home visits in communities by the nursing staff and village health workers were highlighted as a means of increasing the number of men in PMTCT. In addition, they also found opportunities to educate people and mobilise men during community events such as funerals, farmers' field days, weddings and at meetings organised by the chiefs and village headmen:

'At this facility there are community health nurses and village health workers that go and assess [the] community's livelihoods and knowledge about HIV. We had meetings with the chiefs, village headmen and ward counsellors requesting permission to educate their people about health issues. Their support was helpful because village headmen went on to gather all adults in their respective villages, including men, to come and attend educational sessions. We also took advantage of these sessions to educate people about the importance of male involvement in PMTCT.' (Henry, male, 43 years)

Conducting home visits enabled men to attend sessions without any need to travel to the nearest health facility. It is also important to note that home visits provided men with an opportunity to discuss and ask questions in groups, as very few men went to health facilities to seek health services.

Community campaigns and road shows were of significant value in motivating male partners to take part in PMTCT programmes. These were done by the district health institutions in collaboration with governmental and nongovernmental organisations implementing health-related projects, the local community, churches and traditional leaders:

'For our programme to succeed, since we embarked on it in Gokwe North District we involved the community. We conducted community campaigns encouraging the men to accompany their wives to the hospital so that they can be tested together. This approach enables men to be involved in whatever activity the woman has been assigned to during pregnancy. So, when they both get tested, they are provided health education on how to prevent the unborn baby from being infected, especially when they are positive.' (Tom, male, 37 years)

The findings revealed that outreach programmes such as road shows, field days and village meetings supported by traditional leaders were essential in bringing men to attend PMTCT programmes.

Assigning a special title to the male involvement campaign played a role in reminding people about the cause of the campaign. The campaign, 'Operation Perekedza Mukadzi Wako' [Accompany Your Female Partner], was a slogan used in the community to refer to the same idea of men accompanying their wives to participate in PMTCT initiatives. Under this campaign, a man was expected to be responsible for ensuring 
that their pregnancy was registered, they were tested for HIV and that their female partner gave birth at a health facility:

'Under "Operation Accompany Your Female Partner", we have been having meetings with village headmen and chiefs to ask for help in encouraging men to bring their wives to the clinic or hospital for ANC. In this case, every headman would pass an instruction that every man must take his female partner to the antenatal clinic. If not, they have to pay something as a way of encouraging the men to be involved. However, this has not been put into practice; it is in the pipeline, encouraging men to bring their wives to the clinic or hospital for ANC.' (Ruth, female, 31 years)

These findings provided evidence that campaigns (referred to as 'operations') played a major role as a means of responding to the crisis. The campaign named 'Operation Perekedza Mukadzi Wako' was used in road shows, workshops, posters and at village meetings as a means of creating awareness and reminding men to go to the antenatal clinics with their wives. The advantage of conducting campaigns was that most campaigns were conducted as a form of entertainment in the form of drama, music and dance.

Communication between couples was one of the ways in which women were able to negotiate with their partners to participate in PMTCT services. The findings of this study revealed that men were more likely to respond swiftly to invitations that were related to work opportunities or to income-generation projects than to HIV or AIDS or any health-related matters:

'The female partner and husband must understand each other and avoid discouragements from peers. The couple must discuss between themselves; otherwise community meetings can be conducted, but it is only through discussing as a couple that can help convince the man to go the clinic with his female partner.' (Mary, female, 24 years)

These results illustrated that men may not always have placed value on the public meetings conducted on PMTCT, whereas communication between couples facilitated getting men to consider participating in the PMTCT programmes.

It was also clear that men tended to cooperate when issues on their health, HIV and other related matters were discussed in private:

'If you talk about HIV to men in public, they may not take such issues seriously. If the female partner introduces the subject in private and asks him to help out and accompany her to the clinic, he may respect her request and go with her.' (Ivy, female, 38 years)

This quote highlighted that dialogue between couples was a necessary tool that enabled male partners to co-operate on the issues raised by their spouses. It was also important to note that in such discussions, men preferred that the woman persuaded them or asked for support, rather than just giving instructions. The quote above revealed that men tended to respect their wives if they asked with humility and introduced the discussions in their private spaces.

\section{Stigmatisation}

Participants in the study revealed that stigmatisation against men who often accompanied their wives to a health facility was highly discouraging. It was commonly believed that only women should be going to the clinic or hospital. Once a man accompanied his female partner to the health facility frequently, the couple were labelled as HIV positive:

'[T]he people in the community will suspect that the couple is HIV positive. It gives an impression that the couple has not been faithful to each other. However, they cannot say it aloud because it is not permitted by law to discriminate against someone or to label them on the grounds of HIV status.' (Rumbi, female, 22 years)

These results demonstrate that HIV-related stigma discouraged men from participating in PMTCT programmes and that HIV was strongly regarded as an infection that resulted from promiscuity. In addition, the male partner was considered as the one responsible for introducing the infection amongst couples.

Additionally, a man who was often seen going to a health facility with his female partner could also be labelled as having been charmed by his female partner. The use of charms is an African traditional practice where specific herbs are believed to have supernatural powers that enable manipulation of an individual(s) or a situation. As such, men who may have wanted to participate in PMTCT intervention programmes feared being mocked, as one respondent explained:

'[T]he man becomes a laughing stock as people conclude that he has been charmed by his female partner (dzinenge dzakadyiswa, meaning "seems like he was charmed").' (Sue, female, 45 years)

According to the Shona traditional practices and beliefs, the use of charms has the effect of diminishing a man's ability to discern what is wise or not, and what he is supposed to do as a man or not. By using charms, his female partner will have authority over him. As a result of this belief, the men ended up refraining from attending PMTCT activities for fear of stigmatisation.

Participants in the study also explained that as a result of being charmed, a man's ability to reason and make decisions became limited, and his female partner controlled the affairs of the family. One of the participants in the FGDs stated that 'some people will say that he cannot do anything on his own. He is being ruled by the female partner and has become a toy' (Rose, female, 36 years). Other men could also discourage them, saying, '[w]e begin to say that he is not in his mind any more, he is insane and mad' (Tim, male, 48 years). Within the same FGD, a male participant described how women also stigmatised men who participated in PMTCT programmes: 'They will say, "What does he want among women? These issues are for women"' (Pat, male, 33 years). Similarly, a female participant in another FGD also stated that ' $[s]$ ome will say he has nothing to do. It is because he has nothing 
to do so he is always loitering around with the female partner' (Tendai, female, 26 years). These results showed how traditional beliefs, customs and practices negatively impacted men's participation in PMTCT programmes. The use of charms on men was believed to diminish their ability to discern and behave in ways that were expected of them as men, and their ability to make decisions as the head of the household was also thought to be reduced.

\section{Lack of knowledge of human immunodeficiency virus testing}

Participants in this study also identified a lack of knowledge regarding HIV testing. Prevention of mother-tochild transmission programmes considered couple HIV counselling and testing as an entry point for couples to benefit from the services for PMTCT of HIV. It was revealed that some men did not go and obtain these services, as they thought that once their wives were tested and obtained negative test results, that their wives' results automatically reflected their own HIV status:

'They always say that women's results reflect theirs as well; zvauri ndozvandiri [your status and mine are the same] ... yet it is not like that. The answer is simple, lack of knowledge. If one says, your results are a reflection of mine, then it is simply a lack of knowledge. But lack of knowledge is the first reason, but there could be other reasons.' (Rudo, female, 37 years)

The study also revealed that when a woman tested HIV positive, her spouse may not even have considered going to be tested as well; he would simply have concluded that he had a positive HIV status as well. The respondents highlighted that the understanding of the possibility of serodiscordant couples seemed to be limited:

' $[T]$ hey say that the status of their female partner will be the same as theirs. If the female partner tests positive, they will consider themselves as positive. If the female partner tests negative, they will consider themselves as negative, which is not that because they could be discordant.' (Ruth, female, 31 years)

These ideas illustrated that some men would not consider testing for HIV as long as their female partner was tested. This was because some men considered their female partner's HIV status as a proxy for their own, and because of this perception, they saw no need for going to the antenatal clinics with their pregnant wives for an HIV test. It also emerged from the data that for them, PMTCT was synonymous with testing for HIV as a couple during pregnancy, so they saw no need to attend any of the programmes related to PMTCT.

\section{Fear of an human immunodeficiency virus- positive test result}

Results from the study revealed that some men were not participating in activities related to PMTCT, such as HIV testing, as they feared being diagnosed as HIV positive. This fear resulted from previous or current risky behaviour, such as having sexual intercourse with multiple partners. In addition to that, they also feared the negative social consequences associated with an HIV-positive test result:

'Fear is also a problem among men as some have multiple concurrent relationships. Men consider themselves as "bulls", and so they can have many partners. Hence, they know that they are at risk of infection and yet they fear to come for testing.' (Ruth, female, 31 years)

According to this quote, it was a common understanding and was widely acceptable for men to have more than one sexual partner, although this behaviour put them at risk of getting infected with HIV because of their exposure to many sexual partners. It was widely believed that it was men rather than women who had extramarital affairs, and men feared being told that they were HIV positive, as this would expose them as having had an affair. When a couple or the female partner tested positive, the man would be blamed for infecting his spouse:

'Men do not want to know their status. Should they test HIV positive, there will be conflict in the house. For example, I am faithful and he is the definitely the one who would have brought the virus between us.' (Tsitsi, female, 23 years)

This quote illustrated that society did not expect married women to be involved in extramarital relations, yet no such restrictions were applied to married men and it was socially acceptable and expected for them to do so.

The study also identified the concerns surrounding the fear of HIV testing amongst men. Treatment for their HIV was thus a challenge as they could not be provided with medication unless they got tested and prescribed the medication. A male respondent explained this view:

'The main problem is that most of us who are here do not want to know our HIV status. That is the problem. It is also difficult to prevent something when we do not know whether we have [it] or not; it is a problem. So the main issue is that we need to go and get tested so that we know how to take care of our children and make plans for anything in future.' (James, male, 40 years)

The study identified a challenge that was associated with serodiscordant couples, specifically where a woman received a positive test result compared with her husband's result. Fear of conflict as a result deterred women from testing or disclosing their positive test results to their husbands lest they get divorced. What was also interesting to note in this study was that women would accept their partner's positive result and take care of him whilst the opposite was not common amongst men:

'The biggest difficulty is that when a woman tests HIV positive and her husband tests HIV negative, it creates social discord in the community. There are some men in the community whose behaviour is [such] that when he tests negative while his female partner tests HIV positive he divorces her; but if he tests positive and the female partner negative, the female partner will not divorce her husband.' (Ruva, female, 36 years) 


\section{Discussion}

The involvement of traditional leaders, namely chiefs and village headmen, was important in encouraging men to take part in PMTCT programmes. Support from this leadership facilitated the success of other programmes conducted by the health practitioners and other organisations implementing the PMTCT programmes in the district. Similarly, the role of African traditional leaders as custodians of culture and as instruments in curbing HIV infection has been documented by a number of studies conducted in Southern Africa. The Southern Africa HIV and AIDS Information Dissemination Service (SAFAIDS) reported that in a dialogue conducted with traditional leaders from a few Southern African countries, the leaders discouraged all negative cultural practices that fuelled HIV infection and promoted those that facilitated HIV prevention (SAFAIDS 2012). In a study conducted amongst traditional leaders in Zimbabwe to examine traditional marriage practices, the results showed that certain traditional marriage practices were discouraged as they fuelled the spread of HIV and encouraged gender-based violence against women (Marashe 2014). A study conducted in 14 Sub-Saharan African countries shows that direct involvement of leaders in healthcare systems are crucial, particularly in HIV prevention (Karan, Hartford \& Coates 2017). Moreover, the findings drawn from studies conducted in Malawi and Zimbabwe (Kululanga, Sundby \& Chirwa 2011; Ndaimani et al. 2019) found that involving traditional leaders in strategies to improve male partners' involvement in PMTCT yielded positive results. These findings highlight the significance of African traditional systems in promoting public health interventions including HIV in settings where traditional customs and belief systems are observed.

The provision of a first and fast service to women who brought their partners to the antenatal clinics or for postnatal services proved to be one of the factors that facilitated MPI in PMTCT programmes. This study's findings concurred with those of Kululanga et al. (2011), who reported a similar approach in Malawi, which resulted in considerable numbers of male partners accompanying their wives. However, this approach has two weaknesses. A number of studies generally agree that incentives can help to promote socially valuable behaviour across diverse populations (Mathauer \& Imhoff 2006; Ranganathan \& Lagarde 2012; Silverman et al. 2016), but they may not always be a permanent solution to the problem. Secondly, this specific form of incentive may discriminate against single mothers.

Sensitisation campaigns played a vital role in encouraging male partners to take part in the PMTCT initiatives that were conducted in the communities and at the health facilities. Similarly, various campaigns have been conducted in Zimbabwe as a result of different social, political and economic calamities. Although some of these campaigns did have negative consequences on the livelihoods of the affected people (Bratton \& Masunungure 2007; Jones 2010), they were an influential means of addressing problems faced in the country. Some of the operations such as Operation Murambatsvina [Restore Order], Operation Garikai/ Hlalani Kahle [Live Well], Operation Chinyavada [Scorpion] and Operation Pendi Iripi [Where Is the Electoral Ink?] were conducted in a military style to respond to the social, economic and political problems facing the country (Potts 2006; Sachikonye 2006). The major shortcoming associated with this approach is that although it is known to be a powerful means of promoting change in health beliefs, behaviour and practices (Brown \& Singhal 1999), campaigns are in essence short-lived and may not influence long-term behaviour change (Kululanga et al. 2011). Whilst each campaign served a specific purpose, this study demonstrates that sensitisation campaigns as well as the naming that comes with each of these are powerful forces of mobilising communities.

Couple communication played a role in advancing the male partners' involvement agenda. Male partners were not only motivated by public invitations but considered their participation crucial if the issue was addressed directly to them by their wives. One of the plausible explanations for this finding was that some men only considered responding to the invitation if their wives raised the issue and asked them to participate. Previous studies (Dunlap et al. 2014; Kalembo et al. 2012; Kululanga et al. 2011; Nkuoh \& Meyer 2016) demonstrated that the use of invitation letters addressed to males from the health facilities encouraged males to take part in PMTCT programmes. This current study showed that women could openly invite their partners to attend PMTCT activities, a contrasting finding from a study by Njunga and Blystad (2010), which showed that women were scared of taking invitation letters to their partners for fear of violence and confrontation.

On the issue of education, it was found that men seemed to be less informed than women as far HIV health education was concerned. This finding is not new. Previous studies (Hawthorne \& Tomlinson 1997; Kripalani \& Weiss 2006) pointed out that most health education programmes were conducted with patients receiving healthcare services within health facilities, and that there were fewer men who presented themselves at health facilities in comparison with the numbers of women (Möller-Leimkühler 2002; Smith, Braunack-Mayer \& Wittert 2006). Similarly, a study conducted in Zimbabwe among pregnant women portrays lack of education by the male partner as one of the high risk factors contributing to HIV sero-conversion (Mbizvo, Kasule \& Mahomed et al. 2001). Gender research describes cultural norms on masculinity and helps to explain their linkages to such poor health-seeking behaviour amongst men (Creighton \& Oliffe 2010). The results of this study showed that because of poor knowledge of PMTCT, most men would consider couple counselling during pregnancy as the end of their involvement in PMTCT health facility-based programmes, yet it was expected to be an entry point into processes to prevent MTCT. These results concurred with 
studies where male partners presented themselves for only two or a few visits at health facilities between antenatal and postnatal attendances (Mohammed et al. 2019). These results underscored the need to provide sufficient knowledge to men and ensure that they were familiar with the processes involved in PMTCT of HIV programmes.

The study found that African traditional culture and beliefs in the use of magical charms played a role in shaping male partners' responses to PMTCT initiatives. Men who accompanied their wives to obtain PMTCT services were labelled as jealous, overprotective or charmed. In most African traditional settings, domestic responsibilities regarding childcare, the seeking of healthcare services and other activities related to children's well-being were considered as women's duties, whereas the men were only required to provide what was needed in the home (Culley, Hudson \& Lohan 2013; Nkuoh et al. 2010; Ramirez-Ferrero \& Lusti-Narasimhan 2012; Walston 2005). Hence, men who took part in PMTCT programmes were viewed as having been charmed by their woman to reduce their masculine powers. Beyers (2010) stated that in African traditional religion, magical charms played a significant role as a means of controlling the supernatural powers. In explaining the powers of magical charms, Banda (2019) argued that traditional Africans used magical charms to control the spiritual realm to act favourably and benevolently towards them. This study highlighted the complexities that exist in trying to curb the HIV infection whilst at the same time taking cognisance of the belief systems and culture inherent in most African traditional communities.

Fear of a positive HIV test result was highlighted as a deterrent, preventing men from utilising PMTCT programmes. This fear was described as emanating from their risky sexual behaviour of having unprotected sex with multiple partners. Additionally, the negative social consequences associated with a positive result included stigma and discrimination. Similar results were reported in studies conducted in East Africa (Maeri et al. 2016; Turan et al. 2011). This study's findings concurred with previous studies, which stated that people who did not return to collect their HIV test results usually feared stigma, divorce and discrimination (Meiberg et al. 2008; Molitor et al. 1999; Sullivan et al. 2004). Providing sufficient counselling on the implications of an HIV test result and designing strategies aimed at reducing social stigma can be useful tools in addressing HIV-related stigma and discrimination.

\section{Conclusion}

This article explored the factors hindering and enabling male partners' involvement in PMTCT programmes. The study found that African traditional systems played a significant role in influencing the community's response to male partners' participation in PMTCT programmes. The local traditional leadership were influential in motivating and sensitising their communities on MPI. Health service providers came up with initiatives within health institutions and villages, in collaboration with traditional leaders, to provide platforms for ensuring that male partners benefitted from PMTCT services. This approach facilitated the attendance of male partners in community health education forums, awareness campaigns and males utilising antenatal and postnatal care services with their female partners. The major barriers to MPI included stigmatisation against couples who visited the clinic together, as they were assumed to have HIV. In addition, the male partners were believed to have been given traditional charms that are believed to have the effect of diminishing a man's ability to discern what is wise or not, and what he is supposed to do as a man or not. Additionally, fear of a positive HIV test result was highlighted as a deterrent, preventing men from utilising PMTCT programmes. Future studies can further explore the missing gaps in male health service provision, which might facilitate their utilisation of HIV services.

\section{Acknowledgements Competing interests}

The author declares that she has no financial or personal relationships that may have inappropriately influenced her in writing this research article.

\section{Author's contribution}

V.C. is the sole author of this research article.

\section{Ethical considerations}

The research was conducted in line with the research ethical guidelines of the Human and Social Sciences Research Ethics Committee, University of KwaZulu-Natal and the Medical Research Council of Zimbabwe, Ethical clearance number: HSS/0003/014D. Informed consent was obtained from participants who agreed to take part in the interviews. Confidentiality was maintained when reporting the findings of the study.

\section{Funding information}

This research received no specific grant from any funding agency in the public, commercial or not-for-profit sectors.

\section{Data availability}

Data is available upon reasonable request.

\section{Disclaimer}

The views and opinions expressed in this article are those of the author and do not necessarily reflect the official policy or position of any affiliated agency of the author. 


\section{References}

Aarnio, P., Olsson, P., Chimbiri, A. \& Kulmala, T., 2009, 'Male involvement in antenatal HIV counselling and testing: Exploring men's perspectives in rural Malawi', AIDS Care STDS 21(12), 1537-1546. https://doi.org/10.1080/ 09540120902903719

Banda, C., 2019, 'Managing an elusive force? The Holy Spirit and the anointed articles of Pentecostal prophets in traditional religious Africa', Verbum et Ecclesia 40(1), 1-10. https://doi.org/10.4102/ve.v40i1.2025

Beyers, J., 2010, 'What is religion? An African understanding', HTS Teologiese Studies/ Theological Studies 66(1), a341. https://doi.org/10.4102/hts.v66i1.341

Beyers, J., 2017, 'Religion and culture: Revisiting a close relative', HTS Theological Studies 73(1), 1-9. https://doi.org/10.4102/hts.v73i1.3864

Bratton, M. \& Masunungure, E., 2007, 'Popular reactions to state repression: Operation Murambatsvina in Zimbabwe', African Affairs 106(422), 21-45. https:// doi.org/10.1093/afraf/adl024

Brown, W.J. \& Singhal, A., 1999, 'Entertainment-education media strategies for social change: Promises and problems', in D.P. Demers \& K. Viswanath (eds.), Mass media, social control and social change: A macrosocial perspective, pp. 263-280, lowa University Press, Ames.

Creighton, G. \& Oliffe, J.L., 2010, 'Theorising masculinities and men's health: A brief history with a view to practice', Health Sociology Review 19(4), 409-418. https:// doi.org/10.5172/hesr.2010.19.4.409

Culley, L., Hudson, N. \& Lohan, M., 2013, 'Where are all the men? The marginalization of men in social scientific research on infertility', Reproductive BioMedicine Online 27(3), 225-235. https://doi.org/10.1016/j.rbmo.2013.06.009

Demographic and Health Survey, 2016, Key indicators, Zimbabwe National Statistics Agency, Harare.

Dudgeon, M.R. \& Inhorn, M.C., 2004, 'Men's influences on women's reproductive health: Medical anthropological perspectives', Social Science \& Medicine 59(7), 1379-1395. https://doi.org/10.1016/j.socscimed.2003.11.035

Dunlap, J., Foderingham, N., Bussell, S., Wester, C.W., Audet, C.M. \& Aliyu, M.H., 2014 'Male involvement for the prevention of mother-to-child HIV transmission: A brief review of initiatives in East, West, and Central Africa', Current HIV/AIDS Reports 11, 109-118. https://doi.org/10.1007/s11904-014-0200-5

Hawthorne, K. \& Tomlinson, S., 1997, 'One-to-one teaching with pictures--flashcard health education for British Asians with diabetes', British Journal of General health education for British
Practice 47(418), 301-304.

Jones, J.L., 2010, 'Nothing is straight in Zimbabwe': The rise of the Kukiya-kiya economy 2000-2008', Journal of Southern African Studies 36(2), 285-299. https:// doi.org/10.1080/03057070.2010.485784

Kalembo, F.W., Yukai, D., Zgambo, M. \& Jun, Q., 2012, 'Male partner involvement in prevention of mother to child transmission of HIV in sub-Saharan Africa: Successes, challenges and way forward', Preventive Medicine 2(1), 35-42. https:// doi.org/10.4236/ojpm.2012.21006

Karan, A., Hartford, E. \& Coates, T.J., 2017, 'The potential for political leadership in HIV/AIDS communication campaigns in sub-Saharan Africa', Global Health Action 10(1), 1270525. https://doi.org/10.1080/16549716.2017.1270525

Kripalani, S. \& Weiss, B.D., 2006, 'Teaching about health literacy and clear communication', Journal of General Internal Medicine 21(8), 888-890. https://doi. org/10.1111/j.1525-1497.2006.00543.x

Kululanga, L.I., Sundby, J. \& Chirwa, E., 2011, 'Striving to promote male involvement in maternal health care in rural and urban settings in Malawi-a qualitative study', Reproductive Health 8(1), 1. https://doi.org/10.1186/1742-4755-8-36

Mabachi, N.M., Brown, M., Sandbulte, M., Wexler, C., Goggin, K., Maloba, M. et al., 2020, 'Using a social support framework to understand how HIV positive kenyan men engage in PMTCT/EID care: Qualitative insights from male partners', AIDS and Behavior 24(1), 18-28. https://doi.org/10.1007/s10461 019-02451-6

Maeri, I., El-Ayadi, A., Getahun, M., Charlebois, E., Akatukwasa, C., Tumwebaze, D. et al., 2016, "'How can I tell?" Consequences of HIV status disclosure among couples in eastern African communities in the context of an ongoing HIV "testand-treat" trial', AIDS Care 28(suppl 3), 59-66. https://doi.org/10.1080/0954012 1.2016.1168917

Makoni, A., Chemhuru, M., Chimbetete, C., Gombe, N., Bangure, D. \& Tshimanga, M., 2016, 'Factors associated with male involvement in the prevention of mother to child transmission of HIV, Midlands Province, Zimbabwe, 2015-a case control study', BMC Public Health 16(1), 331. https://doi.org/10.1186/s12889016-2939-7

Manjate-Cuco, R.M., Munguambe, K., Bique Osman, N., Degomme, O., Temmerman M. \& Sidat, M.M., 2015, 'Male partners' involvement in prevention of mother-tochild HIV transmission in sub-Saharan Africa: A systematic review', SAHARA-J: Journal of Social Aspects of HIV/AIDS 12(1), 87-105. https://doi.org/10.1080/172 90376.2015.1123643

Marashe, J., 2014, 'The African traditional religious landscape: An examination of the role of traditional leaders in the fight against HIV and AIDS in Chipinge, Zimbabwe', Verbum et Ecclesia 35(1), 1-8. https://doi.org/10.4102/ve.v35i1.871

Mathauer, I. \& Imhoff, I., 2006, 'Health worker motivation in Africa: The role of nonfinancial incentives and human resource management tools', Human Resources for Health 4(1), 24. https://doi.org/10.1186/1478-4491-4-24

Mbizvo, M.T., Kasule, J., Mahomed, K. \& Nathoo, K., 2001, 'HIV-1 seroconversion incidence following pregnancy and delivery among women seronegative at recruitment in Harare, Zimbabwe', The Central African Journal of Medicine 47(5), 115-118. https://doi.org/10.4314/cajm.v47i5.8600
Medley, A., Garcia-Moreno, C., Mcgill, S. \& Maman, S., 2004, 'Rates, barriers of HIV serostatus disclosure among women in developing countries: Implications for prevention of mother-to-child transmission programme', Bulletin of World Health prevention of mother-to-child
Organisation 82, 299-307.

Meiberg, A.E., Bos, A., Onya, H.E. \& Schaalma, H.P., 2008, 'Fear of stigmatization as barrier to voluntary HIV counselling and testing in South Africa', East African Journal of Public Health 5(2), 49-54.

Mohammed, B.H., Johnston, J.M., Vackova, D., Hassen, S.M. \& Yi, H., 2019, 'The role of male partner in utilization of maternal health care services in Ethiopia: A community-based couple study', BMC Pregnancy and Childbirth 19(1), 28. https://doi.org/10.1186/s12884-019-2176-z

Molitor, F., Bell, R.A., Truax, S.R., Ruiz, J.D. \& Sun, R.K., 1999, 'Predictors of failure to return for HIV test result and counseling by test site type', AIDS Education and Prevention 11(1), 1.

Möller-Leimkühler, A.M., 2002, 'Barriers to help-seeking by men: A review of sociocultural and clinical literature with particular reference to depression', Journal of Affective Disorders 71(1-3), 1-9. https://doi.org/10.1016/S0165 0327(01)00379-2

Moser, C., 1993, Gender planning and development, Routledge, London.

Msuya, S.E., Mbizvo, E.M., Hussain, A., Uriyo, J., Sam, N.E. \& Stray-Pedersen, B., 2008 , 'Low male partner participation in antenatal HIV counselling and testing in northern Tanzania: Implications for preventive programs', AIDS Care 20(6), northern Tanzania: Implications for preventive prog
700-709. https://doi.org/10.1080/09540120701687059

Mvumi, B.M. \& Marimo, N., 2011, HIV/AIDS Medium Term Programme component review, Swiss Agency for Development and Cooperation.

Ndaimani, A., Chitsike, I., Haruzivishe, C. \& Stray-Pedersen, B., 2019, 'An exploration of barriers and enablers of retention in a program to reduce vertical transmission of HIV at health centers in Zimbabwe', International Journal of Preventive Medicine 10(1), 74. https://doi.org/10.4103/ijpvm.IJPVM_471_17

Ngara, R., 2019, 'The selection and installation of Shangwe chiefs in Gokwe North and South districts of Zimbabwe: An applied ethnomusicological dimension towards violating an indigenous model', Indilinga African Journal of Indigenous Knowledge Systems 18(1), 78-89.

Ngure, K., Trinidad, S.B., Beima-Sofie, K., Baeten, J.M., Mugo, N.R., Bukusi, E.A. et al., 2017, 'The role of male partners in women's participation in research during pregnancy: A case study from the partners demonstration project', Reproductive Health 14(3), 160. https://doi.org/10.1186/s12978-017-0424-0

Njunga, J. \& Blystad, A., 2010, 'The divorce program: Gendered experiences of HIV positive mothers enrolled in PMTCT programs-the case of rural Malawi', International Breastfeeding Journal 5(14). https://doi.org/10.1186/1746-4358-5-14

Nkuoh, G.N. \& Meyer, D.J., 2016, 'An assessment of strategies used to encourage male involvement in antenatal care and women's uptake of PMTCT services in Cameroon', African Journal of Midwifery and Women's Health 10(1), 34-41. https://doi.org/10.12968/ajmw.2016.10.1.34

Nkuoh, G.N., Meyer, D.J., Tih, P.M. \& Nkfusai, J., 2010, 'Barriers to men's participation in antenatal and prevention of mother-to-child HIV transmission care in Cameroon, Africa', Journal of Midwifery \& Women's Health 55(4), 363-369. Cameroon, Africa', Journal of Midwifery \&
https://doi.org/10.1016/j.jmwh.2010.02.009

Organisation of Public Health Interventions and Development (OPHID), 2015 , Male participation in PMTCT: Survey on the experiences, atttitudes and perspectives of male partners in antenatal and PMTCT services Mashonaland East perspectives of male partners in antenatal and PMTCT services Mashonaland East
Province, Zimbabwe, Organisation for Public Health Interventions and Province, Zimbabwe,
Development, Harare.

Parpart, J.L., Connelly, M.P. \& Barriteau, E. (eds.), 2000, Theoretical perspectives on gender and development, International Development Research Centre, Ottawa.

Potts, D., 2006, 'Restoring order'? Operation Murambatsvina and the urban crisis in Zimbabwe', Journal of Southern African Studies 32(2), 273-291. https://doi. org/10.1080/03057070600656200

Powell, R.A. \& Single, H.M., 1996, 'Focus groups', International Journal for Quality in Health Care 8(5), 499-504. https://doi.org/10.1093/intqhc/8.5.499

Ramirez-Ferrero, E. \& Lusti-Narasimhan, M., 2012, 'The role of men as partners and fathers in the prevention of mother-to-child transmission of HIV and in the promotion of sexual and reproductive health', Reprod Health Matters 20(39), 103-109. https://doi.org/10.1016/S0968-8080(12)39642-0

Ranganathan, M. \& Lagarde, M., 2012, 'Promoting healthy behaviours and improving health outcomes in low and middle income countries: A review of the impact of conditional cash transfer programmes', Preventive Medicine 55(Suppl 1), S95-S105. https://doi.org/10.1016/j.ypmed.2011.11.015

Reece, M., Hollub, A., Nangami, M. \& Lane, K., 2010, 'Assessing male spousal engagement with prevention of mother-to-child transmission (PMTCT) programs in western Kenya', AIDS Care 22(6), 743-750. https://doi.org/10.1080/09540 120903431330

Sachikonye, L.M., 2006, The impact of Operation Murambatsvina/Clean up on the working people in Zimbabwe, LEDRIZ, Harare.

Southern Africa HIV \& AIDS Information Dissemination Service (SAFAIDS), 2012, Traditional leaders on the frontline addressing harmful cultural practices to reduce gender-based violence and HIV in southern Africa, Southern African HIV AIDS Information Dissemination Service, Pretoria.

Silverman, K., Jarvis, B.P., Jessel, J. \& Lopez, A.A., 2016, 'Incentives and motivation', Translational Issues in Psychological Science 2(2), 97-100. https://doi.org/ $10.1037 /$ tps 0000073

Smith, J.A., Braunack-Mayer, A. \& Wittert, G., 2006, 'What do we know about men's help-seeking and health service use?', Medical Journal of Australia 184(2), 81. https://doi.org/10.5694/j.1326-5377.2006.tb00124.x 
Sullivan, P.S., Lansky, A., Drake, A. \& Hits-2000 Investigators, 2004, 'Failure to return for HIV test results among persons at high risk for HIV infection: Results from a multistate interview project', JAIDS Journal of Acquired Immune Deficiency
Syndromes 35(5), 511-518. https://doi.org/10.1097/00126334-200404150-00009

Theuring, S., Mbezi, P., Luvanda, H., Jordan-Hader, B., Kunz, A. \& Harms, G., 2009, 'Male involvement in PTMCT services in Mbeya Region, Tanzania', AIDS Behaviour 13, S92-S102. https://doi.org/10.1007/s10461-009-9543-0

Tolhurst, R., Leach, B., Price, J., Robinson, J., Ettore, E., Scott-Samuel, A. et al., 2012, 'Intersectionality and gender mainstreaming in international health: Using a feminist participatory action research process to analyse voices and debates from the global south and north', Social Science \& Medicine 74(11), 1825-1832. https://doi.org/10.1016/j.socscimed.2011.08.025

Tonwe-Gold, B., Ekouevi, D.K., Bosse, C.A., Toure, S., Kone, M., Becquet, R. et al., 2009 'Implementing family-focused HIV care and treatment: The first 2 years' experience of the mother-to-child transmission-plus program in Abidjan, Cote d'Ivoire', Tropical Medicine and International Health 14(2), 204-212. https://doi. org/10.1111/j.1365-3156.2008.02182.
Turan, J.M., Bukusi, E.A., Onono, M., Holzemer, W.L., Miller, S. \& Cohen, C.R., 2011 'HIV/AIDS stigma and refusal of HIV testing among pregnant women in rural Kenya: Results from the MAMAS study', AIDS and Behavior 15(6), 1111-1120. https://doi.org/10.1007/s10461-010-9798-5

Walston, N., 2005, Challenges and opportunities for male involvement in reproductive health in Cambodia, Policy Project/Cambodia, Phnom Penh.

World Health Organisation (WHO), 2009, Integrating gender into HIV/AIDS programmes in the health sector: Tool to improve responsiveness to women's need, World Health Organisation, Geneva.

World Health Organisation (WHO), 2012, Male involvement in the prevention of mother-to-child transmission of HIV, World Health Organization, Geneva.

Woelk, G., Kieffer, M., Mpofu, D. \& Cathcart, R., 2016, 'Community leader engagement and peer group attendance improves selected $\mathrm{MCH}$ and PMTCT services uptake and retention: Preliminary findings from Project ACCLAIM', Journal of the International AIDS Society 201619. 